\author{
Bogusław BEMBENEK ${ }^{1}$ \\ Katarzyna KOWALSKA ${ }^{2}$
}

\title{
SMES DEVELOPMENT WITHIN INDUSTRIAL CLUSTERS - STRATEGIC CHALLENGE FOR CLUSTER MANAGEMENT
}

\begin{abstract}
The purpose of this article is to characterise the role of industrial clusters in SMEs development. Trying to meet demands of the current environment, these companies are forced to constantly identify new ways of development, including new sources of sustainable competitive advantage. Nowadays, focusing only on the internal (endogenous) development for many entities is insufficient and external development of the SMEs through the clusters may be a complementary approach for their internal development. Despite the scarcity of clear cluster definitions it is widespread that clusters - as concentrations of R\&D entities, business support institutions and interconnected firms operating in the same or related economic sectors that cooperate and compete at the same time - provide favorable conditions for entrepreneurship and innovativeness development. SMEs can improve their market offer, transfer knowledge, formulate and implement R\&D activities, and develop relational capital by actively operating within clusters and collaborating with their partners, both in internal and external environments (eg. involvement in foreign networks). The activities of cluster coordinators play a strategic role in shaping the appropriate conditions for the development of cluster members. Based on the good practice in the field of Polish-Spanish international networking linked to the execution of the "Adelante" project by the coordinator of Sub-Carpathian Renewable Energy Cluster, the benefits for SMEs of that cluster were pointed out. This practice shows that the involvement of a cluster coordinator with key cluster stakeholders for development of cluster members contribute to development of the entire cluster and boost its competitiveness.
\end{abstract}

Keywords: cluster, management, SMEs, development, competitiveness.

\section{INTRODUCTION}

The activity of industrial clusters has strategic importance for the long-term process of transformation that take place in the economy, stimulating the growth of entrepreneurship, innovativeness and competitiveness at micro, meso and macro levels. The entrepreneurial ecosystem of clusters created by the accumulation of values such as knowledge, cooperation of actors forming regional innovation system, coopetition, socio-economic traditions of the region and social capital, provides favourable conditions for business development, in particular for micro, small and medium-sized enterprises (SMEs).

A significant number of SMEs are not able to individually meet the challenges of the current turbulent environment (the amount of change and complexity in the environment)

\footnotetext{
1 Bogusław Bembenek, PhD, Faculty of Management, Rzeszow University of Technology, Poland, Al. Powstańców Warszawy 8, 35-959 Rzeszow, e-mail: bogdanb@prz.edu.pl

${ }^{2}$ Katarzyna Kowalska, PhD student, World Economy Research Institute, Warsaw School of Economics, Poland, Vice-President of UNIMOS Foundation, e-mail: kkowalska@unimos.global
} 
and various development barriers (market-oriented, social, financial, technological, etc.). Globalisation, glocalisation, still growing industrial competition in the area of innovations and technological development, increased level of requirements and customer awareness or local barriers to development are only a few examples of factors that determine SMEs decisions to undertake greater co-operation within the framework of industrial clusters.

The aim of the article is to characterise industrial clusters as an external (exogenous) way of the SMEs development based on selected Polish clustering experiences. The choice of this research problem was related to the fact that SMEs are the most diverse elements of the economy in terms of structure, operation methods, economic potential and flexibility. Being a fundamental element of the structure of clusters, these entities expect synergies resulting from cluster cooperation, the continuous search for new technological, organisational and marketing solutions, the implementation of which will improve their current activities and will strengthen the competitiveness at national and international scale. These expectations provide many new challenges for the cluster management, for example in terms of networking, sustainable development, building trust capital, acquiring new partners for cluster projects, $R \& D$ infrastructure development cluster, and financing cluster activities. Therefore, this kind of cluster management challenges led to three related research questions:

- what distinguishes activity of industrial clusters?

- what is the current role of industrial clusters for SMEs development?

- how does cluster coordinator (cluster organisation) shape the favourable conditions for SMEs development?

The scientific considerations that were presented in the article were based on selected theoretical research results and desk research. In the research process, the most useful research method was the case study. The source of data in qualitative research was coauthor $^{3}$ experience acquired in the implementation of an EU-funded project aimed at developing SMEs through international cooperation between Polish and Spanish clusters. This case study was partly determined by phenomenological paradigm because of the holistic view of the phenomenon and knowledge generation based on participant observation (the observation extends beyond naturalistic observation because the observer is a "player" in the action). The choice of this method resulted from the conviction of the authors that the case of successful project executed by the cluster may be a source of inspiration for various cluster stakeholders.

\section{SMES AS A KEY COMPONENT OF INDUSTRIAL CLUSTERS}

Industrial clusters are widely discussed in the scientific literature, because cluster concept is still a popular topic and various types of industrial clusters exist. In particular, there are two types of industrial clusters that can be found among commercial activities today: industrial clusters that historically developed in many areas around the world, and more recently modern industrial clusters that were formed or initiated by entrepreneurial

\footnotetext{
${ }^{3}$ K. Kowalska was the main author of project "Adelante" and a project manager. She is co-founder of Unimos.Global (European cross-sectoral organisation focused on building trust-based partnerships between business, science, administration and clusters that foster growth and international development) and an expert in area on: internationalisation, export promotion and international cooperation.
} 
individuals ${ }^{4}$. Multiple different factors (endo- and exogenous) induce the formation of industrial clusters worldwide ${ }^{5}$. Therefore, still there is no universally accepted definition of industrial cluster. The economic literature provides many definitions of what an industrial cluster is, for example:

- one of new combined methods of various theories such as theory of economic geography, financial geography, regional economics, national innovation system, transmitting knowledge theories, social capital theories and social networks ${ }^{6}$;

- structure which is generated and reinforced by a positive feedback process based on a set of advantages that arise from the agglomeration of industrial activities ${ }^{7}$;

- intermediate organisations located in a specific geographical region that are officially or unofficially formed by different enterprises (micro, small, medium and large) with shared goals and unified rules ${ }^{8}$;

- form of territorial "aggregation" between companies operating in the same sector or branch and characterised by specific technical and social relationships among private and public actors 9 ;

- selected sets of multiple autonomous organisations, which interact directly or indirectly, based on one or more agreements between them. The aim of clusters is to gain a competitive advantage for the individual organisations involved and occasionally for the entire cluster as well ${ }^{10}$;

- flexible production platforms with some kind of activity specialisation. Cluster operation can be targeted directly to consumer markets but also to supplies of specific intermediate products. In some cases a cluster is organised as an alliance of equal parties (i.e. firms with similar size and importance), in other cases the organisation is more satellite - like and there is one or few large companies that determine cluster activities according to their input demands ${ }^{11}$;

- a system composed of many industries. The structure of industrial clusters concerns the correlation and interdependent relationship among basic integral parts, namely, among industries. It is determined by the functional and spatial links among industries and in turn, deeply influence these links. Economic links among industries within clusters not only include input-output relationships, but also reflect external economic relationships ${ }^{12}$;

\footnotetext{
${ }^{4}$ G. Tesar, J. Bodin, Marketing management in geographically remote industrial clusters, World Scientific Publishing, London 2013, p. 7.

${ }^{5}$ P. Nie, P. Sun, Search costs generating industrial clusters, “Cities” 2015, no. 42, p. 268.

${ }^{6}$ S.V. Hosseini, M.R. Ghanbari, Investigation and analysis of the performance of industrial clusters in Islamic Republic of Iran, "International Journal of Business and Social Science" 2011, vol. 2, no. 15, p. 231.

${ }^{7}$ R. Baptista, P. Swann, Do firms in clusters innovate more?, "Research Policy" 1998, vol. 27, p. 526.

${ }^{8}$ X. Jia, M. Jiang, T. Ma, The dynamic impact of industrial cluster life cycle on regional innovation capacity, "Economic Research" 2015, vol. 28, no. 1, p. 812.

${ }^{9}$ T. Daddi, M.R. de Giacomo, F. Testa, S. Tessitore, Cluster approach and eco-innovation in four industrial clusters of Tuscany region, "Environmental Economics" 2012, vol. 3, no. 2, p. 26.

${ }^{10}$ G.T. Lin, Ch.-Ch. Sun, Driving industrial clusters to be nationally competitive, "Technology Analysis \& Strategic Management” 2010, vol. 22, no. 1, p. 81

${ }^{11}$ M. Szanyi, P. Csizmadia, M. Illessy, I. Iwasaki, C. Mako, The relationship between supplier networks and industrial clusters: an analysis based on the cluster map ping method, "Eastern Journal of European Studies" 2010, vol. 1, no. 1, p. 90

${ }^{12}$ Z. Yingming, Industrial clusters in China, CRC Press, Boca Raton 2010, p. 1.
} 
- a geographic concentrations of interrelated companies and institutions that colocate around a variety of common interests or needs. It is geographically bounded groups of firms that depend on other nearby firms and institutions for their livelihood in a variety of ways ${ }^{13}$;

- a group of geographically close and interacting leading companies and affiliated organisations which act in specific economy sphere of the region, which are closely connected with each other in the framework of industrial, technological, scientific of interactions ${ }^{14}$;

- a business and living area that comprises a large variety of firms that are relatively homogenous in production activities and constituted by socioeconomic structures. A community of firms in the area is embedded socially as a community of people, in support of trust and reciprocal relationships, that gets involved in transactions. Market relations between cluster firms can be organised on the basis of mutual cooperation and competition (coopetition) ${ }^{15}$.

According to P. Morosini an industrial cluster is a socioeconomic entity characterised by a social community of people and a population of economic agents localised in close proximity in a specific geographic region. The ultimate goal of this kind cluster is to generate superior products and services that are valuable to customers in the marketplace. Within an industrial cluster, a significant part of both the social community and the economic agents work together in economically linked activities, sharing and nurturing a common stock of product, technology and organisational culture. In a well-developed industrial cluster, these linkages can be numerous, unique and specialised ${ }^{16}$.

There are various types of definitions of industrial clusters identified in the literature. Two main approaches to defining industrial clusters have developed over the last 20 years: clusters based on inter-industry linkages inferred from multi-region analysis and cluster definitions based on observed linkages among industries or firms in a single region ${ }^{17}$.The most important definition of industrial cluster was given by Michael Porter, because he focused primarily on the dynamics of industry clustering. For this paper an industrial cluster was defined as a cross-industry system that arise in certain locations based on buyer-supplier relations (vertical relations) and the coopetition relations between competitors in the market (horizontal relations), interconnected firms (SMEs and large) and institutions connected with them (e.g. universities, standardisation institutions and industrial associations). Geographic, cultural, technological and institutional proximity provide companies with special access, closer relationships, better information, powerful incentives, and other advantages that are difficult to tap from a distance ${ }^{18}$. Porter's notion

\footnotetext{
${ }^{13}$ S. Rosenfeld, Industry clusters: business choice, policy outcome, or branding strategy?, "Journal of New Business Ideas and Trends" 2005, vol. 3 (2), p. 8.

${ }^{14}$ A.V. Babkin, T.J. Kudryavtseva, S.A. Utkina, Identification and analysis of industrial cluster structure, "World Applied Sciences Journal" 2013, vol. 28 (10), p. 1408.

${ }^{15} \mathrm{P}$. Ismalina, An integrated analysis of socioeconomic structures and actors in Indonesian industrial clusters, University of Groningen, Groningen 2011, p. 49.

${ }^{16} \mathrm{P}$. Morosini, Industrial clusters, knowledge integration and performance, „World Development” 2004, vol. 32, no. 2, pp. 307-309.

${ }^{17}$ M. Delgado, M.E. Porter, S. Stern, Defining clusters of related industries, "National Bureau of Economic Research Working Paper Series", no. 20375, Cambridge 2014, p. 6.

${ }^{18}$ M. Porter, Clusters and the new economics of competition, "Harvard Business Review" 1998, no. 76 (6), pp. $77-90$
} 
of 'industrial clusters' is easily the most popular and well known. Moreover, has become the standard concept in the field of promoting national, regional or local competitiveness, innovation and growth.

Many researchers stress that the industrial cluster is the new phenomenon of the development of companies and regional economies ${ }^{19}$. It can play a significant role in stimulating the regional development and strengthening the local-global linkage. The creation of industrial clusters has been regarded as an important strategy to improve the competitive advantage of a national economy and to cope with the fierce global economic competition $^{20}$. Furthermore, an industrial cluster has great influence on the optimisation of regional industrial layout and regional economic structure ${ }^{21}$.

L.W. Munnich argues that firms within certain industries have a tendency to cluster geographically within urban areas. The nature of the process by which industrial clusters emerge within urban areas has, in recent years, become a major topic of study in fields such as urban economics and economic development policy. Industries with higher location quotients are assumed to be more competitive, representing "traded" clusters that sell a larger share of their output outside the immediate region ${ }^{22}$. The development of industrial clusters is considered as an effective alternative approach to building a competitive advantage for the industries in particular and the region in general. Moreover, it can be used to develop broad industries that focus on the types of products with high international competitiveness in both domestic and global markets ${ }^{23}$.

In the formation of industrial clusters, special economic zones make a prominent contribution to national economic development, and are thus important indices of industry cluster development ${ }^{24}$. Tax reliefs are one of the instruments for the new projects promotion in special economic zones used widely as an element of industrial policy, both in developing and highly developed countries. The aim of the special economic zones is to attract new, high-tech enterprises that can contribute to export growth, sustained modernisation of the regional economic structure, effective use of local resources in a sustainable way, stimulating the local job market, and creating a cooperation network between the actors of the regional innovation system. The formation of industrial clusters cannot be achieved by the market mechanism alone because the harmonisation of suitable economic policies and cluster policies is also required ${ }^{25}$.

${ }^{19} \mathrm{Z}$. Qing, The research on influence of industrial clusters on regional economic development, "Procedia IERI" 2012, vol. 3, p. 206.

${ }^{20} \mathrm{~J}$. Wang, Institutional change and the development of industrial clusters in China, World Scientific Publishing, Singapore 2014, pp. 3, 15.

${ }^{21}$ Z. Yuxiang, Z. Xilai, L. Chun, Y. Feng, W. Hongyu, The development strategy for industrial clusters in Qingdao, "Energy Procedia" 2011, no. 5, p. 1355.

${ }^{22}$ L.W. Munnich, M. Iacono, J. Dworin, B. Brandt-Sargent, Transportation planning to support economic development: an exploratory study of competitive industry clusters, Minnesota Department of Transportation Research Services \& Library, Saint Paul 2015, p. 1.

${ }^{23}$ H. Nazif, S. Darma, B. Herdiyanto, E.H. Purwanto, An opportunity to develop industrial cluster based geothermal energy to improve local competitiveness of North Maluku province - Indonesia, Proceedings World Geothermal Congress , Melbourne 2015, p. 4.

${ }^{24}$ Y.L. Lai, M.S. Hsu, F.J. Lin, Y.M. Chen, Y.H. Lin, The effects of industry cluster knowledge management on innovation performance, "Journal of Business Research" 2014, vol. 67, p. 736

${ }^{25}$ A. Kuchiki, M. Tsuji, Industrial clusters, upgrading and innovation in East Asia, Edward Elgar, Cheltenham 2011, p. 5. 
An industrial cluster is still perceived as the source of a lot of advantages for the cluster members functioning in their structures and the countries in which they are located (Table 1). The biggest advantage of the cluster approach is that the group of people share a common prospect or problem; hence they can unanimously decide and come to a solution. This is one of the advantages of partnership within cluster, especially where the partners have different skills and can work well together ${ }^{26}$.

Table 1. Key benefits for industrial cluster members

Characteristics of selected benefits/advantages:

- industrial cluster development can impel economic growth and urge the formation of a regional innovation system

- industrial cluster plays an important role in a group of competitive, interconnected industries and other entities; through specialisation and collaboration between enterprises within the group established a close relationship between competition and cooperation

- through competition and cooperation (coopetition), members in the cluster complete the human resource distribution and establish economic and technological relationships based on inputoutput analyses

- the appropriate support agencies, to provide various services such as local governments, industry associations, the financial services sector and education and training institutions

- the concentration and collaborative ties of companies promote efficiency and productivity

- clusters offer companies easy access to important resources, lower transport costs, access to customers and the workforce

- cluster in many ways to establish an environment conducive to innovation, face to face communication between people in the cluster and the mobility of labour, to speed up the flow of business knowledge, financial knowledge and technical knowledge, to stimulate innovation

- clusters in all sectors can be developed through the construction of internal industrial networks, reduce costs and promote innovation

- the main function of a cluster is to promote innovation (and open innovation)

- within the industrial clusters, improvement of innovation capability relies on the sustainable supply and input of technology development resources from both internal and external

- the improvement of innovation capacity relies on the continuous supply of internal and external technical resources to the industrial cluster, namely talents and academic research, enterprise research and development, and other technological innovation information transfer networks

- division of labour between firms in the cluster can reduce production and transaction costs

- cluster members through joint use of public facilities to reduce the additional investment required to dispersed layout, and use of geographic proximity and save the costs of material and information flow in the inter-migration, thus reducing production costs

- common culture and shared values within cluster is conducive to the establishment of a partnership between cluster members and trust-based social networks, making it both easy to deal and fulfil the contract, thereby reducing transaction costs, but also to make the transaction uncertainty lead to the risk of cost reduction

- cluster formed by establishes a "brand" and leads to the formation of a good brand image among consumers, enhances consumer desire to buy, expand the market competitive advantage

- industrial clusters tend to have the characteristics of cross-regional and cross-industry

\footnotetext{
${ }^{26}$ D. Bhattacharyya, Cottage industry clusters in India in improving rural livelihood: an overview, "International Journal of Humanities \& Social Science Studies" 2014, vol. 1, no. 1, p. 63
} 


\begin{tabular}{l} 
Characteristics of selected benefits/advantages: \\
\hline cluster has an impact on effectiveness of cluster companies, where the effectiveness is under- \\
stood here as the ability to create a competitive advantage for companies functioning within the \\
cluster either directly considered in relation to these entities and countries (or regions) in which \\
clusters exist
\end{tabular}

Source: prepared based on: Z. Qing, The research on influence ..., op. cit., pp. 206-212; K. Cheba, The influence of clusters on economic development. A comparative analysis of cluster policy in the European Union and Japan, "Quarterly Journal Oeconomia Copernicana" 2015, vol. 6, no. 3, p. 78; J. Adams, J. Wang, Industrial clusters and regional economic development in China: the case of "green food", "Journal of Chinese Entrepreneurship" 2009, vol. 1, no. 3, pp. 279-294; X. Jia, M. Jiang, T. Ma, The dynamic impact ..., op. cit., pp. 807-813; Z. Garanti, A. Zvirbule-Berzina, Regional cluster ..., op. cit., pp. 91-97.

Productivity, innovation capacity and an increase in efficiency of geographically concentrated enterprises can contribute to the enterprise competitiveness ${ }^{27}$. The benefits resulting from cluster activities may be divided into material benefits (easily measurable) and intangible assets (difficult to measure). Thus, can be analysed at various levels (cluster members, cluster as an organisation, region and country level) from different perspectives. The economic literature frequently shows that the cluster is used as a tool to create competitive advantages, particularly regarding micro, small and medium-sized enterprises (SMEs). Nowadays, clustering is indeed important for the development of SMEs as well as the region ${ }^{28}$.

The European definition of SMEs including micro (up to 10 employees), small (up to 50 employees) and medium-sized enterprises (up to 250 employees). SMEs represent $99 \%$ of all businesses in the EU. The definition of an SMEs is important for access to finance and EU support programmes targeted specifically at these enterprises ${ }^{29}$. Within a cluster there can exist three different types of $\mathrm{SMEs}^{30}$ :

- first type are SMEs that simply respond to some challenge or local need that is clearly apparent and does not require a great deal of technical knowledge, large investment capital, or significant labour force;

- second type are SMEs that have moved up the technology curve. Over time, these type of companies gain knowledge and experience in operating large-scale production equipment and start to offer design options to their clients;

- third type are SMEs that reflect strong entrepreneurial initiatives (new products, processes, solutions, etc.).

\footnotetext{
${ }^{27}$ Z. Garanti, A. Zvirbule-Berzina, Regional cluster initiatives as a driving force for regional development, "European Integration Studies" 2013, no. 7, p. 97.

${ }^{28}$ T. Tambunan, Promoting small and medium enterprises with a clustering approach: a policy experience from Indonesia, "Journal of Small Business management" 2005, vol. 43 (2), p. 142; A. Karaev, S.C. Koh, L.T. Szamosi, The cluster approach and SME competitiveness: a review, "Journal of Manufacturing Technology Management" 2007, vol. 18, no. 7, pp. 818-835; B.A. Phinaitrup, Strengthening the competitiveness of SMEs by using the cluster-based approach: a case study of the Ratchaburi Orchid Cluster in Thailand, "Journal of Modern Accounting and Auditing" 2012, vol. 8, no. 2, pp. 195-206.

${ }^{29}$ European Commission, Commission Staff Working document on the implementation of Commission Recommendation of 6 May 2003 concerning the definition of micro, small and medium-sized enterprises, European Commission, Brussels 2009, p. 2; European Commission, Evaluation of the user guide to the SME definition, European Commission, Brussels 2014, p. 2; http://ec.europa.eu/growth/smes/business-friendlyenvironment/sme-definition_pl (access: 1.12.2016).

${ }^{30}$ G. Tesar, J. Bodin, Marketing management ..., op. cit., pp. 35-36.
} 
According to A.P. Muizer and G.J. Hospers, the motives for clustering may differ along with a companies size (cluster members). Moreover, the role and position in industry clusters as well as the characteristics of industry clusters may differ along with a companies size. They stress that the main motives for SMEs to participate in a modern industry cluster are technology-based. In order to reduce the power of uncertainty and maintain competitiveness particularly SMEs may be willing to develop new products, but do not have the economies of scale and scope in the R\&D-function which large firms often do have $\mathrm{e}^{31}$. Clustering can stimulate the development and growth of SME sector, as SMEs that participate in clusters can gain advantage from: an advanced and specialised infrastructure, a qualified workforce, increased possibilities to penetrate new markets, an increased ability to meet the needs of clients, and cost reduction in manufacturing operations $^{32}$. Key factors that have a strong impact on development SMEs within an industrial cluster are e.g.: effect of transportation, effect of market size, effect of adjustment, effect of effectiveness, effect of control, effect of culture ${ }^{33}$.

Polish clusters create an entrepreneurial ecosystem that contribute to boost the development of the Polish SMEs. This ecosystem has an insatiable demand for this kind of enterprise. In order to highlight the importance of SMEs in the development of Polish clusters, selected results of benchmarking surveys conducted among the Polish clusters were used. The Polish Agency for Enterprise Development (PAED) executed three editions (2010, 2012 and 2014) of benchmarking surveys. The purpose was to assess the state of Polish clusters, but also to identify trends in cluster development over the six years. Data for benchmarking analyses was primarily obtained through questionnaire interviews with cluster coordinators, which are defined as legal entities that perform coordinating functions in clusters. The experience of Polish clusters indicated that micro, small and medium-sized enterprises dominated numerically within cluster members. Table 2 shows the structure development of the surveyed clusters by size enterprises during the study period.

Tab. 2. SMEs within polish clusters (cluster benchmarking - edition 2010, 2012, 2014)

\begin{tabular}{|c|c|c|c|c|}
\hline \multirow{2}{*}{$\begin{array}{c}\text { Edition } \\
\text { of studies }\end{array}$} & \multicolumn{4}{|c|}{ Size of firms } \\
\cline { 2 - 5 } & $\begin{array}{c}\text { Micro } \\
<\mathbf{1 0} \text { employees }\end{array}$ & $\begin{array}{c}\text { Small } \\
<\mathbf{5 0} \text { employees }\end{array}$ & $\begin{array}{c}\text { Medium } \\
<\mathbf{2 5 0} \text { employees }\end{array}$ & $\begin{array}{c}\text { Large } \\
>\mathbf{2 5 0} \text { employees }\end{array}$ \\
\hline $\begin{array}{c}\mathbf{2 0 1 0} \\
\mathrm{N}=47 \text { clusters } \\
1469 \text { firms }\end{array}$ & $44 \%$ & $15 \%$ & $29 \%$ & $12 \%$ \\
\hline $\begin{array}{c}\mathbf{2 0 1 2} \\
\mathrm{N}=35 \text { clusters } \\
1137 \text { firms }\end{array}$ & $45 \%$ & $26 \%$ & $21 \%$ & $8 \%$ \\
\hline $\begin{array}{c}\mathbf{2 0 1 4} \\
\mathrm{N}=35 \text { clusters } \\
1559 \text { firms }\end{array}$ & $44 \%$ & $32 \%$ & $18 \%$ & $6 \%$ \\
\hline
\end{tabular}

Source: prepared by the authors based on: Deloitte, Benchmarking klastrów w Polsce - 2010. Raport z badania, PARP, Warszawa 2010, p. 31; J. Hołub, Benchmarking klastrów w Polsce edycja 2012. Raport z badania, PARP, Warszawa 2012, p. 28; B. Plawgo, Cluster benchmarking in Poland - edition 2014. General report, PAED, Warszawa 2014, pp. 6-21.

\footnotetext{
${ }^{31}$ A.P. Muizer, G.J. Hospers, Industry clusters and SMEs, EIM, Zoetermeer 1998, pp. 5-6, 48-49.

${ }^{32}$ V. Navickas, A. Malakauskaite, The impact of clusterization on the development of small and medium-sized enterprise (SME) sector, "Journal of Business Economics and Management" 2009, vol. 10 (3), p. 257.

${ }^{33}$ A.P. Muizer, G.J. Hospers, Industry clusters ..., op. cit., pp. 5-6, 48-49.
} 
The information presented in Tab.2 indicates that micro firms constitute the largest group among cluster members surveyed in each of the three editions of the benchmarking. The second most important group consisted of small business. During the study it was confirmed that SMEs has shown a special interest in participating in this kind of initiative, considering cluster cooperation as a source of several benefits. SMEs were also deciding about the nature, scale and dynamic of development processes in studies clusters. The research has affirmed the natural feature of clusters as a pro-innovation environment. Enterprises belonging to clusters showed higher innovation activity than the average for the entire enterprise population. More than $7 \%$ employment growth has been noted in entities belonging to the group of clusters examined during the last two years (2014 July 2012 July). Given that the number of people employed have virtually remained steady in Poland in that period, the rising employment in clusters is proof that they concentrate entities characterised by great competitiveness and expansiveness ${ }^{34}$.

In 2015 Polish Agency for Enterprise Development (PAED) conducted further studies among Polish clusters. A research project implemented by PAED in 2015 included a cluster stock taking, aimed at establishing the real number of active clusters in Poland. In order to do this, basic data on cluster initiatives has been collected from various sources and validated with respect to correctness and completeness. Then a questionnaire based survey of cluster organisations (coordinators) has been performed in an attempt to collect comprehensive data on clusters and their members. Inventory of clusters operating on the territory of Poland has revealed the total number of 134 active clusters. In these clusters operated 4578 companies and SMEs represented on average $78 \%$ of all cluster members. Chart 1 displays the structure of enterprises in the Polish clusters during the study period.

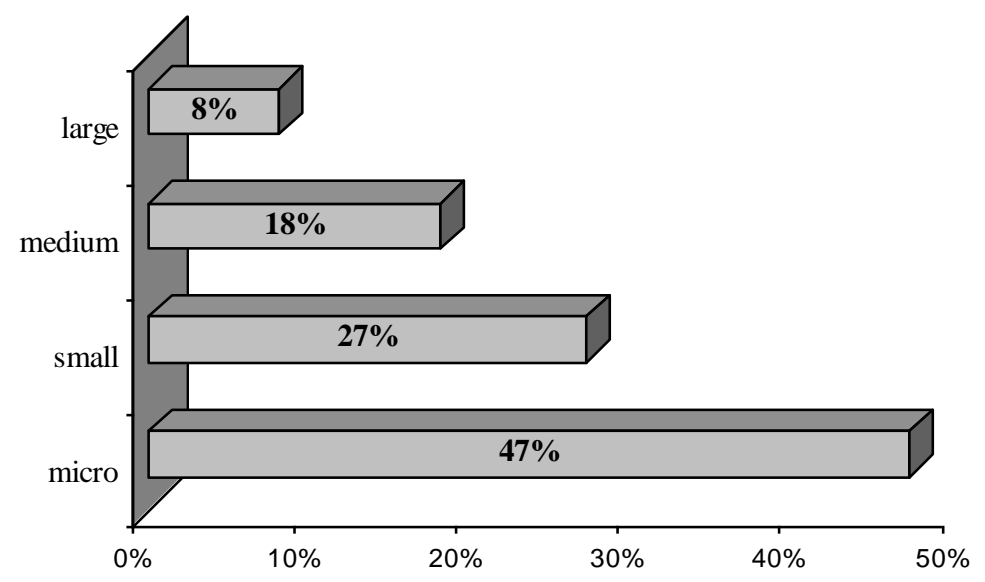

Chart 1. Business structure in clusters based on employment levels (2015, N=4578 enterprises) Source: prepared by the authors based on: G. Buczyńska, D. Frączek, P. Kryjom, Raport z inwentaryzacji klastrów w Polsce 2015, PARP, Warszawa 2016, pp. 22-23.

Apart from the group of clusters actively operating (existing clusters) in Poland, the research also revealed 106 potential clusters (clusters that could operate but do not have sufficient key resources that allow its proper functioning and development). A big part of

\footnotetext{
${ }^{34}$ B. Plawgo, Cluster benchmarking in Poland - edition 2014. General report, PAED, Warszawa 2014, pp. 6-21.
} 
group of potential clusters consisted of public support beneficiaries who either haven't managed to continue collaboration beyond their cluster projects or experienced a significant decline in their activity levels for different reasons. It seems that some of these potential clusters could change into real clusters in the near future ${ }^{35}$.

In Poland, the best conditions for SMEs development offer clusters which acquired the status of Key National Cluster (KNC) and those whose cluster management system is consistent with the standards developed by PAED in 2014. Currently, 16 Polish clusters have active status of $\mathrm{KNC}^{36}$, have strategic importance for the country's economy and are highly competitive. The $\mathrm{KNC}$ are identified at national level by the Ministry of Development that organises a competition procedure based on different criteria including, critical mass, development potential, innovativenes, level of internationalisation, existing and planned cooperation within the cluster and the experience and potential of the cluster coordinator. The analysis conducted by the PAED in 2015 aimed at verifying the degree of compliance of Polish cluster management within the formulated standards has shown that $^{37}$ :

- the cluster management standards should be understood as a code setting basic requirements for coordinators' practice and conduct in running a cluster;

- cluster entities, especially SMEs, have a real basis to verify competences of their coordinators;

- each cluster has been assessed against 36 cluster management standards covering five sections: cluster setup, resources, processes, services for cluster members and external collaboration;

- the overall level of compliance in five sections was as high as $92 \%$ on average;

- from 64 clusters involved in the study - 30 of them have met standards of cluster management;

- from 64 clusters - 5 were in the embryonic growth phase, 58 in the development phase and 1 cluster was in the mature phase;

- Polish clusters are young organisations and, in many cases, cluster coordinators are developing skills of profesional cluster management and effective actions for improving its competitiveness.

Curently, clusters are one of the most dynamic and flexible tools for cooperation of Polish SMEs ${ }^{38}$. Developed standards for cluster management are and will be an important factor in determining the quality of cooperation and management of Polish clusters. Striving for cluster management excellence can provide many new benefits for cluster members, including SMEs.

\footnotetext{
${ }^{35}$ G. Buczyńska, D. Frączek, P. Kryjom, Raport z inwentaryzacji ..., op. cit., p. 10.

${ }^{36} \mathrm{http}: / /$ www.pi.gov.pl/klastry/chapter_95922.asp (access: 1.12.2016).

${ }^{37}$ D. Frączek, P. Kryjom, Weryfikacja standardów zarządzania w wybranych klastrach - edycja 2015, PARP, Warszawa 2016, pp. 6-23.

${ }^{38}$ S. Saniuk, K. Cheba, K. Szopik-Depczyńska, Aspekty planowania sieci produkcyjnych małych i średnich przedsiębiorstw funkcjonujacych w klastrach, [in:] J. Witkowski, A. Skowrońska (ed.), Strategie i logistyka w warunkach kryzysu, nr 382, Prace Naukowe Uniwersytetu Ekonomicznego we Wrocławiu, Wrocław 2015, pp. 377-379.
} 


\section{GOOD PRACTICE FOR SMES DEVELOPMENT WITHIN INDUSTRIAL CLUSTER - A CASE STUDY}

The project "Adelante" was an EU funded initiative implemented during 2014-2015 in the Podkarpackie and Andalusia regions aimed at fostering international cooperation and knowledge transfer between Polish and Spanish SMEs representing eco-energy, smart cities and connected sectors. The aim of the project was to increase the competitiveness, adaptation potential and internationalisation level of micro, small and medium enterprises (SMEs) basing on the Spanish experiences related to renewable energies development, transition to a low carbon economy and creation of smart cities. The project was implemented by an interdisciplinary consortium, consisting of the following institutions: Subcarpathian Renewable Energy Cluster, Rzeszów Regional Development Agency, Andalusian Cluster of Renewable Energies and Energy Efficiency.

The Subcarpathian Renewable Energy Cluster - SREC (in Polish: Podkarpacki Klaster Energii Odnawialnej - PKEO) was a lead partner within project "Adelante". It is a network of inter-sectoral cooperation that brings together more than 80 institutions from private, public, academic and business support institutions representing renewable energy, energy efficiency and new technologies sectors. Established in 2011 and awarded with the prestigious Bronze Label Cluster Excellence ${ }^{39}$, the cluster has experience in organising dozens of training, thematic events, information, education and advisory services, as well as in implementation of EU-funded projects. The cluster's actions aim to create a strong and uniform representation of the interests of entrepreneurs, investors, research and development $(R \& D)$ units as well as other entities working for the development of the environmentally friendly power industry based on renewable energy sources. The main SREC's activities focus on winning new partners, observing and analysing domestic and foreign experiences (good practices) as well as improving contact and communication mechanisms. One of the important assumptions of the strategy is the creation of joint products based on innovative solutions developed with the participation of R\&D units of partner universities. Benefits for the cluster members are different: strong and influential group of partners; access to a R\&D base, business contacts and sectoral news; participation in the creation and implementation of joint products and solutions; strengthening market position and positive image of the company; presentation of the company potential on cluster websites; consistent outside representation of cluster members' interests ${ }^{40}$. The cluster members want to develop international cooperation directed towards: exchange of knowledge and experiences; looking for access to the reliable /standard business cooperation solutions; looking for new markets for the cluster members and their products; looking for access to new technologies, organising cooperation with R\&D units; organising study tours, internships and specialist training; and looking for sources of financing of joint activity ${ }^{41}$.

\footnotetext{
${ }^{39}$ Bronze Label awarded to cluster organisations having taken part in a benchmarking exercise according to the „NGPExcellence-approach“. Benchmarking exercise performed by the European Secretariat for Cluster Analysis (ESCA) relying on an international pool of specifically trained „Cluster Benchmarking Experts“. Validity of the label: two years from month of benchmarking interview http://www.cluster-analysis.org (access: 1.12.2016)

${ }^{40} \mathrm{http}: / /$ www.tci-network.org/initiatives/initiative/4704 (access: 1.12.2016).

${ }^{41}$ PARP, Clusters in Poland, PARP, Warszawa 2012, p. 39.
} 
The Rzeszów Regional Development Agency (RRDA) was a Polish partner within the project. It was established in 1993 as a leading institution for comprehensive development of the Podkarpackie region and specialises in delivering training, consulting, EU projects and implementation of new technologies. The RRDA operates within national and European co-operation networks. It has obtained accreditation with the Polish Agency for the Development of Enterprise as far as training, information, consulting financial as well as pro-innovative services are concerned. It is a member of the National Service System for SME's in Poland and the network of the Innovation Relay Centres in Europe. The Agency employs a team of highly-qualified experts in the fields of law, economics, sociology, finance, architecture and civil engineering, who are dynamic, open-minded and ready to serve local enterprises, government, investors, as well as scientists and all those who contribute to the development of the region ${ }^{42}$.

The Andalusian Cluster of Renewable Energies and Energy Efficiency (CLANER) was established in 2012, promoted by the Andalusian Association of Promoters and Producers of Renewable Energy (APREAN) ${ }^{43}$. The cluster brings together the leaders of development and the use of renewable energy resources and smart cities in Spain. Cluster activities are oriented on research, development and innovation, cooperation with companies and clusters, marketing and support for the internationalisation of its members. This cluster is born thanks to the collaboration of multiple entities in the field of R\&D, to develop and carry out large projects taking advantage of the technological knowledge accumulated throughout years of leadership of the Andalusia's renewable sector companies. The cluster consists of nearly 100 members and aims to keep adding more key actors of the industry ${ }^{44}$.

The target group of the project "Adelante" were SMEs representing eco-energy sector (renewable energy, environment, IT, construction, architectural and related), located in the Podkarpackie region and decided to increase their competitiveness through complex training and advisory support in the field of: strategic management, international financing, marketing, branding and packaging, internationalisation and export consortia. The programme was also focused on building a reliable, cross-sectoral international network of partners based on sharing experiences and transferring good practices from Spain to Poland in order to boost competitiveness, internationalisation and innovation of Polish SMEs. The project "Adelante" was implemented in participatory way focusing on strengthening regional and international linkages between the Podkarpackie and Andalucia regions, including engagement of the scientific and local/regional government institutions. The project includes a number of comprehensive activities, such as:

- transfer of Spanish experiences of renewable energies and smart cities development through a cycle of three thematic informs tailored to the Podkarpackie region economic and social reality;

- organisation of two participatory workshops aimed at identifying current needs and expectations of the SMEs;

- diagnosis of the situation of Polish SMEs carried out by Spanish experts and further elaboration of development plans;

\footnotetext{
${ }^{42} \mathrm{http}: / /$ www.rarr.rzeszow.pl/en/ (access: 1.12.2016).

${ }^{43} \mathrm{http}: / / \mathrm{claner}$.es/en/quienes-somos/ (access: 1.12.2016).

$44 \mathrm{http}: / /$ www.investinandalucia.es/new/show/id/122/title/The-Andalusian-Renewable-Energies-Cluster-is-born (access: 1.12.2016).
} 
- advisory services for Polish companies related to management, marketing, financing and internationalisation processes;

- elaboration of training programmes by Spanish partner;

- e-mentoring for Polish companies executed by Spanish experts;

- elaboration of final casebook and the organisation of a closing conference.

The project "Adelante" represented a useful tool for more than 20 SMEs and its 80 employees, generating several economic, social and technological synergies. The benefits of the project's implementation can be divided into benefits for SMEs, clusters, science and regional government, as well as material and intangible benefits for both entrepreneurial cluster ecosystems. The project was an interdisciplinary initiative with interrelated activities oriented to create technological, economic, social and marketing synergy effects on: business level (between Polish and Spanish SMEs representing eco-energy sectors), scientific and research level (between Polish and Spanish universities), public administration level (between Podkarpackie and Andalucia regional governments), cluster level (between Polish and Spanish clusters coordinating and facilitating project activities). Tangible benefits constituted during project implementation are the following:

- 3 thematic informs related to the development of renewable energy in Spain, transfer of case studies in field of smart cities and casebook - summary of the participatory process and knowledge transfer;

- 2 participatory workshops for Spanish and Polish partners aiming at identifying needs and expectations in terms of renewable energies and smart cities development;

- 21 diagnoses and 21 development plans for Subcarpathian SMEs development prepared by Spanish partner;

- elaboration of four training programs including Spanish experiences and corresponding to the identified needs of companies;

- 320 hours of specialised consulting for SMEs in field of strategic management, internationalisation, marketing and finance;

- organisation of two editions of specialised training (80 hours/edition) for 78 SMEs employees;

- 200 hours of Spanish e-mentoring for the Subcarpathian SMEs development;

- participatory elaboration of final casebook including Polish and Spanish partners;

- organisation of the closing conference, with pitching session that involved 27 SMEs, organisation of the technological exposition of SMEs products and services.

Intangible benefits for SMEs resulting from the implementation of the project are:

- increased level of mutual trust between Polish SMEs participating in a cluster;

- acquisition of specific knowledge about Spanish experiences and good practices about smart cities development;

- increased level of international linkages between Polish and Spanish partners;

- trust building between private, public, scientific and business support institutions.

In addition to the expected project results, several added-value activities took place during the project implementation:

- Smart Cities Innovation Bridge Rzeszów-Malaga cooperation agreement firmed by the Subcarpathian Cluster of Renewable Energies, University of Rzeszów and Andalusian Cluster Renewable Energies and Energy Efficiency; 
- preparation of joint research project for Horizon 2020 call linked to international cluster cooperation;

- letter of intent on collaboration for socio-economic development between Podkarpackie region and Andalucia region;

- invitation to the INTERREG project aimed at improving energy efficiency and an increase the use of renewable energy for electricity production and thermal uses in buildings which is currently implemented by partners from Poland, Spain, Croatia, Lithuania and UK.

The project "Adelante" was an interdisciplinary initiative with several interrelated activities, oriented to create technological, economic, social and marketing synergy effects. Those synergies were possible to achieve, thanks to close cooperation of Polish and Spanish cluster managers and coordinators, engagement of public and scientific institutions and SMEs interest in acquiring new knowledge and developing partnerships with Spanish partners.

\section{CONCLUSIONS}

SMEs form a very important sector of the economy of many countries, including Poland. Their value could be seen, among others, in GDP co-creation, niche market services, developing an entrepreneurial mindset and building an entrepreneurial ecosystem of industrial clusters. This ecosystem shapes a dynamic and interlinked relationship system between various entities (business, $\mathrm{R} \& \mathrm{D}$, business environment and local government). These entities - being concentrated spatially in a given territory and supplying regularly the system's own resources (tangible and intangible) - are more or less interdependent from each other. Functioning within an entrepreneurial ecosystem of industrial clusters creates direct opportunities for SMEs, building better conditions for their development, improving the efficiency of operations, the efficient use of complementary resources and the acquisition of knowledge from cluster members. It provides a solid counterbalance to the negative effects of globalisation that particularly affect SMEs.

Due to the importance of SMEs in the economy, it can be concluded that Polish clusters still need to improve their integrating and coordinating activities. The cluster coordinator performance varies, of course, according to the phase of the cluster cycle life, nature of the industry and cluster development directions. Given that SMEs are the foundation of most of the industrial clusters, it is necessary to undertake by cluster coordinators different activities, such as:

- permanently identifying their problems and barriers to development,

- inventory of its strategic potential,

- creation of adatabase including their current and potential capacities and needs,

- including their needs and expectations in the cluster development strategy,

- motivating to collaborate with R\&D institutions,

- engagement in the cluster projects, co-creation of R\&D and infrastructural cluster projects and to provide relatively stable sources of funding,

- facilitating access to new technologies, specific knowledge and other resources that could contribute to strengthening their competitiveness,

- support in the internationalisation process and integration with global value chains,

- strengthening human capital through different types of trainings for employees of cluster members that can contribute to getting to know each other, 
- identification of sources for specialised and cheaper factors of production,

- updating the database about the possibilities of support under the EU funds, including various programmes,

- identifying sources of potential conflicts between cluster members, including relationships between SMEs and large companies,

- lobbying for the creation of better conditions for business development.

The authors own experience in the area of cooperation with the cluster coordinators indicate that SMEs are an example of exigent cluster members, expecting concrete benefits in a short period of time. Therefore support for current operation and SMEs development offered by cluster coordinators should be multilevel and adequate to current need of cluster members. It should take into account existing barriers for cooperation development at technological, organisational, legal, socio-cultural, economic and financial level. This requires the full engagement of cluster coordinator to overcome existing stereotypes, which may block the realisation of ambitious projects within clusters. It also requires constant cooperation with business environment institutions and local government in order to jointly allow for local SMEs development.

These considerations are the basis for further research on the prosperity of SMEs within a industrial cluster and propensity to implement an open innovation strategy. For a more comprehensive understanding of an SMEs activities in industrial cluster innovation process, this needs to be broadened to include key factors that constrain the adoption of innovation in SMEs and those clusters members who do not want extensive use of innovations. Further work is needed to explore in detail the complementary resources in cluster used by cluster members to achieve specific outcomes. Thus, the prospect research on the attractiveness of industrial clusters for SMEs development is a very broad field.

\section{REFERENCES}

[1] Adams J., Wang J., Industrial clusters and regional economic development in China: the case of "green food", "Journal of Chinese Entrepreneurship" 2009, vol. 1, no. 3, pp. 279-294.

[2] Babkin A.V., Kudryavtseva T.J., Utkina S.A., Identification and analysis of industrial cluster structure, "World Applied Sciences Journal" 2013, vol. 28 (10), pp. 1408-1413.

[3] Baptista R., Swann P., Do firms in clusters innovate more?, "Research Policy" 1998, vol. 27, pp. 525-540.

[4] Bhattacharyya D., Cottage industry clusters in India in improving rural livelihood: an overview, "International Journal of Humanities \& Social Science Studies" 2014, vol. 1, no. 1, pp. 59-64.

[5] Buczyńska G., Frączek D., Kryjom P., Raport z inwentaryzacji klastrów w Polsce 2015, PARP, Warszawa 2016.

[6] Cheba K., The influence of clusters on economic development. A comparative analysis of cluster policy in the European Union and Japan, "Quarterly Journal Oeconomia Copernicana" 2015, vol. 6, no. 3, pp. 73-88.

[7] Daddi T., de Giacomo M.R., Testa F., Tessitore S., Cluster approach and eco-innovation in four industrial clusters of Tuscany region, "Environmental Economics" 2012, vol. 3, no. 2, pp. 26-34.

[8] Delgado M., Porter M.E., Stern S., Defining clusters of related industries, "National Bureau of Economic Research Working Paper Series", no. 20375, Cambridge 2014, pp. 1-47.

[9] Deloitte, Benchmarking klastrów w Polsce - 2010. Raport z badania, PARP, Warszawa 2010. 
[10] European Commission, Commission Staff Working document on the implementation of Commission Recommendation of 6 May 2003 concerning the definition of micro, small and medium-sized enterprises, European Commission, Brussels 2009.

[11] European Commission, Evaluation of the user guide to the SME definition, European Commission, Brussels 2014.

[12] Frączek D., Kryjom P., Weryfikacja standardów zarządzania w wybranych klastrach - edycja 2015, PARP, Warszawa 2016.

[13] Garanti Z., Zvirbule-Berzina A., Regional cluster initiatives as a driving force for regional development, "European Integration Studies" 2013, no. 7, pp. 91-101.

[14] Hołub J., Benchmarking klastrów w Polsce - edycja 2012. Raport z badania, PARP, Warszawa 2012.

[15] Hosseini S.V., Ghanbari M.R., Investigation and analysis of the performance of industrial clusters in Islamic Republic of Iran, "International Journal of Business and Social Science" 2011, vol. 2, no. 15, pp. 231-235.

[16] http://claner.es/en/quienes-somos/ (access: 1.12.2016).

[17] http://ec.europa.eu (access: 1.12.2016).

[18] http://www.investinandalucia.es/new/show/id/122/title/The-Andalusian-Renewable-EnergiesCluster-is-born (access: 1.12.2016).

[19] http://www.rarr.rzeszow.pl/en/ (access: 1.12.2016).

[20] http://www.tci-network.org/initiatives/initiative/4704 (access: 1.12.2016)

[21] http://www.pi.gov.pl/klastry/chapter_95922.asp (access: 1.12.2016).

[22] Ismalina P., An integrated analysis of socioeconomic structures and actors in Indonesian industrial clusters, University of Groningen, Groningen 2011.

[23] Jia X., Jiang M., Ma T., The dynamic impact of industrial cluster life cycle on regional innovation capacity, "Economic Research" 2015, vol. 28, no. 1, pp. 807-829.

[24] Karaev A., Koh S.C., Szamosi L.T., The cluster approach and SME competitiveness: a review, "Journal of Manufacturing Technology Management" 2007, vol. 18, no. 7, pp. 818-835.

[25] Kuchiki A., Tsuji M., Industrial clusters, upgrading and innovation in East Asia, Edward Elgar, Cheltenham 2011.

[26] Lai Y.L., Hsu M.S., Lin F.J., Chen Y.M., Lin Y.H., The effects of industry cluster knowledge management on innovation performance, "Journal of Business Research" 2014, vol. 67, pp. 734-739.

[27] Lin G.T., Sun Ch.Ch, Driving industrial clusters to be nationally competitive, "Technology Analysis \& Strategic Management” 2010, vol. 22, no. 1, pp. 81-97.

[28] Morosini P., Industrial clusters, knowledge integration and performance, „World Development" 2004, vol. 32, no. 2, pp. 307-309.

[29] Muizer A.P., Hospers G.J., Industry clusters and SMEs, EIM, Zoetermeer 1998.

[30] Munnich L.W., Iacono M., Dworin J., Brandt-Sargent B., Transportation planning to support economic development: an exploratory study of competitive industry clusters, Minnesota Department of Transportation Research Services \& Library, Saint Paul 2015.

[31] Navickas V., Malakauskaite A., The impact of clusterization on the development of small and medium-sized enterprise (SME) sector, "Journal of Business Economics and Management" 2009, vol. 10 (3), pp. 255-259.

[32] Nazif H., Darma S., Herdiyanto B., Purwanto E.H., An opportunity to develop industrial cluster based geothermal energy to improve local competitiveness of North Maluku provinceIndonesia, Proceedings World Geothermal Congress , Melbourne 2015.

[33] Nie P., Sun P., Search costs generating industrial clusters, "Cities" 2015, no. 42, pp. 268-273.

[34] PARP, Clusters in Poland, PARP, Warszawa 2012.

[35] Phinaitrup B.A., Strengthening the competitiveness of SMEs by using the cluster-based approach: a case study of the Ratchaburi Orchid Cluster in Thailand, "Journal of Modern Accounting and Auditing” 2012, vol. 8, no. 2, pp. 195-206. 
[36] Plawgo B., Cluster benchmarking in Poland - edition 2014. General report, PAED, Warszawa 2014.

[37] Porter M.E., Clusters and the new economics of competition, "Harvard Business Review" 1998, no. 76 (6), pp. 77-90.

[38] Qing Z., The research on influence of industrial clusters on regional economic development, "Procedia IERI" 2012, vol. 3, pp. 206-212.

[39] Rosenfeld S., Industry clusters: business choice, policy outcome, or branding strategy?, "Journal of New Business Ideas and Trends" 2005, vol. 3 (2), pp. 4-13.

[40] Saniuk S., Cheba K., Szopik-Depczyńska K., Aspekty planowania sieci produkcyjnych małych $i$ średnich przedsiębiorstw funkcjonujacych $w$ klastrach, [in:] J. Witkowski, A. Skowrońska (ed.), Strategie i logistyka w warunkach kryzysu, nr 382, Prace Naukowe Uniwersytetu Ekonomicznego we Wrocławiu, Wrocław 2015, pp. 376-388.

[41] Szanyi M., Csizmadia P., Illessy M., Iwasaki I., Mako C., The relationship between supplier networks and industrial clusters: an analysis based on the cluster map ping method, "Eastern Journal of European Studies" 2010, vol. 1, no. 1, pp. 87-112.

[42] Tambunan T., Promoting small and medium enterprises with a clustering approach: a policy experience from Indonesia, "Journal of Small Business Management" 2005, vol. 43 (2), pp. 138-154.

[43] Tesar G., Bodin J., Marketing management in geographically remote industrial clusters, World Scientific Publishing, London 2013.

[44] Wang J., Institutional change and the development of industrial clusters in China, World Scientific Publishing, Singapore 2014.

[45] Yingming Z., Industrial clusters in China, CRC Press, Boca Raton 2010.

[46] Yuxiang Z, Xilai Z., Chun L., Feng Y., Hongyu W., The development strategy for industrial clusters in Qingdao, "Energy Procedia" 2011, no. 5, pp. 1355-1359.

\section{ROZWÓJ MŚP W RAMACH KLASTRÓW PRZEMYSLOWYCH - STRATEGICZNE WYZWANIE W ZARZĄDZANIU KLASTRAMI}

Przedmiotem artykułu jest charakterystyka roli klastrów przemysłowych w procesie rozwoju mikro, małych i średnich przedsiębiorstw (MŚP). Przedsiębiorstwa te chcąc sprostać wymogom współczesnego otoczenia coraz częściej zmuszone są do identyfikacji wciąż nowych sposobów rozwoju, w tym źródeł względnie trwałej przewagi konkurencyjnej. Koncentracja jedynie na rozwoju wewnętrznym (endogenicznym) dla wielu podmiotów gospodarczych jest obecnie niewystarczająca. Komplementarnym dla rozwoju wewnętrznego jest rozwój zewnętrzny na przykład poprzez działalność w ramach klastrów przemysłowych. W artykule podkreślono, że w literaturze ekonomicznej wciąż brakuje jednolitego podejścia w definiowaniu tego typu klastrów. Pomimo braku jednoznacznej definicji w tym obszarze, upowszechniło się przekonanie, że klastry jako skupisko podmiotów sektora $\mathrm{B}+\mathrm{R}$, instytucji otoczenia biznesu, a w szczególności wzajemnie powiązanych firm, działających w tych samych i/lub pokrewnych sektorach gospodarki, wspólpracujących i konkurujących ze sobą (koopetycja), zapewniają dogodne warunki dla rozwoju przedsiębiorczości i innowacyjności. MŚP funkcjonując aktywnie w strukturze klastrów przemysłowych mogą podejmować wspólnie ze swymi partnerami działania z zakresu doskonalenia oferty rynkowej, transferu wiedzy, projektowania i realizacji prac $\mathrm{B}+\mathrm{R}$, rozwoju kapitału relacyjnego w środowisku wewnętrznym i zewnętrznym klastrów (m.in. poprzez udział klastra w międzynarodowych sieciach). W kształtowaniu właściwych warunków dla rozwoju członków klastrów strategiczne znaczenie ma aktywność koordynatorów klastrów. Bazując na dobrej praktyce koordynatora Podkarpackiego Klastra Energii Odnawialnej, w zakresie sieciowania polsko-hiszpańskiego, wskazano na korzyści, jakie dostarczyła realizacja projektu „Adelante” dla MŚP tego klastra. Praktyka ta pokazuje, że 
zaangażowanie koordynatora klastra na rzecz rozwoju członków klastra, wspólnie z kluczowymi interesariuszami klastra, wpływa jednocześnie na rozwój całego klastra, wzmacniając jego konkurencyjność.

Slowa kluczowe: klaster, zarządzanie, MŚP, rozwój, konkurencyjność.

\section{DOI: 10.7862/rz.2016.mmr.41}

Tekst złożono w redakcji: grudzień 2016

Przyjęto do druku: grudzień 2016 